and the Maritime provinces visiting architects, building contractors and wholesale and retail lumber dealers.

Mr. Jacques' experience ranges from wholesale and retail lumber and millwork sales with A. S. Nicholson and Son Limited, through plywood and wallboard distribution with International Panelboards Limited and Canusa Building Products Limited where he was Sales Manager. He assumes his new post following sales promotion work as Ontario representative of Trafalgar Mills Limited of Newcastle, New Brunswick, and Rothwell Sales Company, Vancouver.

\title{
Ottawa Man Named for Aerial Photography Award
}

R. D. Davidson, B.A.Sc., D.L.S., Technical Advisor to the Director of Military Survey in the Department of National Defence, Ottawa, was selected to receive an award by Canadian Kodak Co., Limited, in recognition of more than forty years of outstanding service to Canada in the fields of surveying, air photography and photogrammetry.

The Award was made to mark this year's Golden Anniversary of Flight in Canada and was presented at the Annual Luncheon of The Canadian Institute of Surveying in Ottawa, January 29. Mr. Davidson was chosen by the Council of the Institute.

Born in March, 1892, Mr. Davidson obtained his degree of Bachelor of Applied Science from the University of Toronto in 1914 and the following year was commissioned as a Dominion Land Surveyor in the Topographic Surveys Section of the Department of the Interior. In 1932 he joined the survey section of the Branch of the General Staff, Department of National Defence, where he has served ever since.

A well-known pioneer in Canadian air survey, Mr. Davidson has long been connected with aerial photography and the use of photogrammetry for mapping in Canada. In 1923 he was the navigator on the first RCAF photographic sortie and in 1924 he was navigator for a similar operation in the Reindeer - Lake Manitoba area, an operation which was considered an epic flight in the annals of early aviation.

Mr. Davidson is in control of the Shoran photographic operations which supply the geographic position fixes needed for topographic mapping of an area of some 1,000,000 square miles in Northern Canada.

\section{News From Laval}

\section{Forest Research Greenhouse Inaugurated at Laval}

A new research greenhouse was inaugurated on February 24th last at the Laval Faculty of Forestry by President Percy Fox of the Quebec Forest Industries Association, on behalf of thirty contributing member firms.

The greenhouse is annexed to the school building and consists of a matching stone headerhouse, $45^{\prime} \times 14^{\prime}$, and of the glasshouse itself, a $62^{\prime} \times 25^{\prime}$ construction containing six independent research units, $10^{\prime} \times 21.5^{\prime}$, under a common roof.

Work in these units is to be distributed as follows: 